\title{
Microplastic Release from Domestic Washing
}

\author{
Suna Ozden Celik ${ }^{1 *}$ \\ ${ }^{1}$ Tekirdag Namik Kemal University, Corlu Engineering Faculty, Departmant of Environmental Engineering, Tekirdag, Turkey, (ORCID: 0000-0001-9783-9512), \\ sunacelik@nku.edu.tr
}

(First received 05 May 2021 and in final form 16 August 2021)

(DOI: $10.31590 /$ ejosat.933322)

ATIF/REFERENCE: Celik, S., O. (2021). Microplastic Release from Domestic Washing. European Journal of Science and Technology, (25), 790-795.

\begin{abstract}
Plastics have been used by human beings in a wide variety of materials. Recently, microplastics, either primary or secondary, are encountered in different part of the environment on a global scale. One of the common type of microplastic is micro fiber. Microfibers are known to be released from washing of textile materials. The amount of released fiber varies depending on the washing conditions and fiber characterization. Microplastics can be harmfull for aquatic organisms. Moreover, because long term effect of microplastic is unclear, the situation about microplastic is unpredictable at the future. Therefore, it is aimed in this study to evaluate the release of microfiber from domestic laundry washing operations. 5 washing cycles were studied with domestic type washing machine. Fiber release per washing and $\mathrm{kg}$ washed textile material were determined according to the results of the gravimetric analysis. According to the results, cotton textile materials have a higher shedding tendency than synthetic polyester materials. Fiber release varied from 13.1 $\mathrm{mg} / \mathrm{kg}$ to $15.66 \mathrm{mg} / \mathrm{kg}$ depending on $\%$ blend of washed textile materials. Most of the fibers were trapped with $100 \mu \mathrm{m}$ filter, suggesting most of the fibers released from washing in the range of 100-200 $\mu \mathrm{m}$.
\end{abstract}

Keywords: Microplastic, Release, Domestic, Washing.

\section{Evsel Çamaşır Yıkamadan Oluşan Mikroplastik Salınımı}

Öz

Plastikler, insanlar tarafından çok çeşitli materyallerde kullanılır. Son zamanlarda çeşitli çevre bileşenlerinde birincil ve ikincil mikroplastiklere global ölçekte rastlanmaktadır. Mikro fiber, yaygın mikroplastik tiplerinden birisidir. Mikrofiberlerin tekstil materyallerinin yıkanmasından salındığı bilinmektedir. Salınan microfiber miktarı, yıkama koşulları ve fiber karakteristiğine göre değişir. Mikroplastikler sucul organizmalar için zararlı olabilmektedir. Bunun yanında, mikroplastiklerin uzun dönem etkileri bilinmediğinden, gelecekte mikroplastikten kaynaklanabilecek durum tahmin edilemez durumdadır. Bu sebeple, bu çalışmada evsel çamaşır yıkama işleminden salınan mikroplastiğin değerlendirilmesi amaçlanmıştır. Evsel tip çamaşır makinesi ile 5 yıkama döngüsü çalışılmıştır. Gravimetrik analiz sonuçlarına göre, yıkama başına ve yıkanan kilogram tekstil başına fiber salınımı belirlenmiştir. Sonuçlara göre, koton tekstil materyali, sentetik polyestere göre daha fazla dökme eğilimi göstermekedir. Fiber salınımı yıkanan tekstil materyalinin \% karışımına bağlı olarak $13.1 \mathrm{mg} / \mathrm{kg}$ ile $15.6 \mathrm{mg} / \mathrm{kg}$ arasında değişmektedir. Tutulan fiberlerin büyük bir kısmının $100 \mu \mathrm{m}$ filtre ile tutulması, fiberlerin çoğunun 100-200 $\mu \mathrm{m}$ aralığında olduğunu göstermektedir.

Anahtar Kelimeler: Mikroplastik, Salınım, Evsel, Yikama.

\footnotetext{
*Corresponding Author: sunacelik@nku.edu.tr
} 


\section{Introduction}

Plastic production has rapidly increased since 1950's and has nowadays reached to 368 million tons capacity (Plastics Europe, 2020). Plastics have been used by human beings in a wide variety of materials since it was invented. Although some plastic products are recycled at the end of their usefull life, significiant amount of plastics have become waste. Thus, plastic wastes are encountered in different part of the environment; even it disposed properly. Plastic pollution causes harmfull effect on human and other living beings, affects all organisms via food chain (Akçay et al., 2020).

Microplastics can be expressed as plastic particles that are smaller than $1 \mathrm{~mm}$ (Browne et al. 2007). One of the common microplastic type is fibers which are encountered in the environment, originating from textile materials. It is determined that $35 \%$ of microplastics in the oceans are fiber type plastics (Boucher \& Friot, 2017). Synthetic microfiber ingestion was shown to increase the mortality of living organisms such as Daphnia magna (Jemee et al., 2016).

Textile industry is a growing market depending on global demand for textiles. Synthetic fibers are more durable, less expensive and have good elasticity. As a consequence of these advantages, usage of synthetic fiber in textile production is common. Since textile production increases on global scale, released microfibers from textile materials will increase, inevitably. Moreover, since plastics are essential to modern life, it seems the human beings can't give up plastic usage. The characterization and release mechanism of microfibers are not clearly understood, yet. Moreover, long term effects of microplastics are also not clear. Manufacturers use microbeads to provide scrubbing effect to some personal care products such as toothpastes, body scrub, exfoliaters etc. Microbeads contain small microplastics. Several countries, such as USA, Canada, United Kingdom, Sweden, France and Taiwan have banned microbeads in personal care products thanks to the improvement of awareness on environmentally friendly products (Davvergne, 2018). As the studies on microplastics increase, the precautions, which can be taken, will be implemented to minimize the risk, in future.

Some of the studies about fiber type microplastic investigate the effect of washing conditions and production processes such as cutting, sewing etc. on fiber release (Cai et al., 2020; Zambrano et al., 2021; Sait et al., 2021, Fontana et al., 2020; Almroth et al., 2018), while others investigate the impact of fiber type on fiber release (Galvao et al., 2020; Karkkainen \& Silanpaa, 2021, Napper \& Thompson, 2016, De Falco et al., 2018). Cai et al. (2020) studied release of microfibers from 12 different textile materials. It is found in this study that microfiber release was varied from 210 to 72000 microplastic/g textile material. They revealed that cutting method has significiant impact on fiber release (Cai et al., 2020). Fontana et al. (2020), used $100 \%$ polyester textile material to investigate fibre releasing during 3 different washing conditions. Released fibers were filtered through $40 \mu \mathrm{m}$ filter and removed fibres were determined milligram microfiber per kilogram textile materials in their study. According to the results, it was concluded that microplastic release were depended on fibre structure and washing conditions. It is also found in this study that soft washing conditions gave lower microplastic release. Karkkainen
\& Silanpaa (2021) quantified the release of different fibres originating from washing and drying activity. They used two commercial fibre traps to investigate the removal efficiency of microfibre release from polyester, polyamide and polyacryl textile. According to the results two commercial fibre traps removed only $39 \%$ and $10 \%$ of polyester fibres from washing effluent. The mass of the trapped fibres were varied from 10 to $1700 \mathrm{mg} / \mathrm{kg}$ for first drying activity. The mass of released fibre decreased during sequential washing and drying activities.

The situation about microplastic release from washing acitivities is still unclear. As it shown from the examples, the amount of released fibre varied due to experimental conditions. As a first study conducted in Turkey, in this study 5 different washing cycles were studied in the view of fibre release in domestic type washing conditons. Washing effluent was sequentially filtered through $200 \mu \mathrm{m}, 100 \mu \mathrm{m}, 50 \mu \mathrm{m}$ and $5 \mu \mathrm{m}$, polypropylene filters and fibre release was determined as \% weight of released fibres. Thus, it is aimed to reveal the size distribution of released fibres from washing of textile materials.

\section{Material and Method}

\subsection{Compositons of the Washing Cycles}

The composition of the 5 washing cycles in terms of $\%$ blend ratio of the textile fibre type, and the weight of the each textile materials were determined, before washing experiments. The detailed compositions are given at Table 1. Blend ratios of each washing experiment differed in terms of $\%$ cotton and polyester. The dominant fibre type was cotton in the first washing experiment, while it was polyester in the second experiment. Thus, it is aimed to investigate the impact of $\%$ ratio of fibre blend on fibre release, as well.

\subsubsection{Washing Conditions}

Bosch Max7 Vario Perfect/WAE20464TR laundry machine was used for the experiments. Load of washing was kept constant at $2 \mathrm{~kg}( \pm 0.1)$ to provide much easier comparison conditions of washing cycles. Performed washing program was selected as "Mix" with Speed Perfect acceleration. Washing temperature, the rotational speed of the tumble and washing duration were $40^{\circ} \mathrm{C}, 1000 \mathrm{r} / \mathrm{min}$., 53 minute, respectively.

Prior the each washing experiment, washing machine was operated empty in the "Super Fast" program, during 15 minute. In the "Super Fast" program, the washing temperature and rotational speed of the tumble were $40^{\circ} \mathrm{C}$ and $1000 \mathrm{r} / \mathrm{min}$. After each washing experiment, washing effluent was drained in 60 litre of volume polyethylene container. Three 500 mililiters of samples were taken from stirred effluent, simultaneously. Then, these three samples were mixed and 250 mililiter volume of sample was taken and used for each washing cycle. Samples were filtered immediately after sampling, through $200 \mu \mathrm{m}, 100$ $\mu \mathrm{m}, 50 \mu \mathrm{m}$ and $5 \mu \mathrm{m}$ polypropylene filters. Filters were dried at $105{ }^{\circ} \mathrm{C}$ during 30 minute, then cooled to room temperature at dessicator in petri dishes and weighted immediately with KERN ABS 120-4 analytical balance. The mass of the fibres on the filter were calculated and recorded. 
Table 1. Composition of the textile materials washed

\begin{tabular}{|c|c|c|c|c|c|}
\hline Washing No & Composition & Total weight (g) & Fiber type \% & Synthetic \% & Synthetic weight (g) \\
\hline 1 & $\begin{array}{c}2 \text { jumpers } \\
3 \text { sweatshirts } \\
1 \text { vest } \\
2 \text { sportswear }\end{array}$ & 2068 & $\begin{array}{c}\text { Cotton } 60 \% \\
\text { Polyester } 40 \%\end{array}$ & 40 & 827 \\
\hline 2 & $\begin{array}{c}1 \text { jumpers } \\
3 \text { sweatshirts } \\
4 \text { tshirts } \\
2 \text { shirts } \\
1 \text { sportswear }\end{array}$ & 2047 & $\begin{array}{l}\text { Cotton } 40 \% \\
\text { Polyester } 60 \%\end{array}$ & 60 & 1228 \\
\hline 3 & $\begin{array}{c}1 \text { blanket } \\
1 \text { table mat } \\
1 \text { vest }\end{array}$ & 2101 & Polyester $100 \%$ & 100 & 2101 \\
\hline 4 & 2 bed sheet & 2085 & Cotton $100 \%$ & 0 & 0 \\
\hline 5 & $\begin{array}{c}1 \text { blanket } \\
1 \text { bed sheet }\end{array}$ & 2106 & $\begin{array}{c}\text { Cotton } 70 \% \\
\text { Polyester } 30 \%\end{array}$ & 30 & 632 \\
\hline
\end{tabular}

\section{Results and Discussion}

\subsection{Retained Fibre Variation for Varying Filter}

According to the results of the gravimetric analysis, reteained fibres from five washing experiments were given in Figure 1. As shown from Figure 1, $100 \mu \mathrm{m}$ filter gave the highest fibre removal in all washing experiments. The amounts of retained microfiber through $200 \mu \mathrm{m}$ were close to the amount of the retained microfiber by $100 \mu \mathrm{m}$ filter Released fibre per liter of washing effluent was calculated by dividing the amount of the microfiber retained in the filter, into effluent sample volume and given in Table $2 \mathrm{as} \mathrm{mg} / \mathrm{l}$. Total removed fibre per washing varied between $3.28 \mathrm{mg} / 1$ and $3.91 \mathrm{mg} / \mathrm{l}$ for five washing experiments.

\subsection{The Effect of \% Blend on Fibre Release}

As can be seen from Table 2, the highest amount of fibre released from 4th washing. Textile materials, washed in this experiment contain $100 \%$ cotton, while Washing 3 contains 100 $\%$ polyester textile material. Second highest fibre released in 5th washing experiment. Similarly, cotton blend ratio was higher than the others in this washing experiment. Washing experiment 2 gave the lowest fibre release.

Released fibre depends on washing conditions, such as washing load, tumble rotation rate, temperature, detergent, softener etc. Shedding characteristics of textile materials also depend on fiber type, fabric structure, etc. Additionaly, new clothes release relatively more microfibers than older clothes (Sillanpaa \& Sainio, 2017; Kelly et al., 2019; Cesa et al., 2020; Belzagui et al., 2019). However, because the study aimed to compare fibre release under the same washing conditions, these parameters were not varied in this study. Therefore, variation in shedding performances possibly was resulted from fiber type and fabric structure.

Total release of fibre $(\mathrm{mg} / \mathrm{kg})$ per washing experiment was determined for washing 3 (100\% polyester) and Washing 4 (100 $\%$ cotton) to compare the results with other studies in the literature (Table 3). Total release of fibre ( $\mathrm{T}, \mathrm{mg} / \mathrm{kg}$ ) per washing experiment can be calculated by using the following equation:

$$
\mathrm{T}=\frac{\mathrm{FxE}}{\mathrm{W}}
$$

Where $\mathrm{F}$ is the retained microfiber by filter, $\mathrm{E}$ is the effluent volume, and $\mathrm{W}$ is the total weight of the washed textile material.

Washing effluent was 32 liter in all experiments. Variation of the total release of fibre per washing experiment was evaluated also in the view of filter size (Figure 2). As shown from Figure 2, $100 \mu \mathrm{m}$ filtre gave the highest fibre removal in all washing experiments. Additionaly, as it can be seen from Table 2 , total fiber per washing was $15,66 \mathrm{mg} / \mathrm{kg}$ for Washing 4 , while it was found $13.27 \mathrm{mg} / \mathrm{kg}$ for Washing 3 .

Some researchers used different methods and admitted some factors to calculate the total release from microplastic such as length and density of fiber. But accuracy of these admits is worth discussing. Although, our results are relatively lower than some previous studies (Boucher and Friot, 2017), the results are in line with Belzagui et al. (2019) and Sillanpaa \& Sainio (2017). According to the results, cotton textile materials have a higher shedding tendency than synthetic polyester materials. The higher the $\%$ blend of cotton, resulted in higher fibre release. Sillanpaa and Sainio (2017), also reported cotton textile materials have a higher shedding tendency than others. Our results are in accordance with Sillanpaa\& Sainio (2017).

Combining polyester with cotton in textile material, results in strengthened and durable material. Additionaly, polyester blending with cotton reduce costs (Baykal et al., 2006). Therefore polyester was used frequently blended with other fabrics. However, it is stated in the study conducted by Napper \& Thompson (2016) that significiantly lowers fibres were released from polyester-cotton textile material, than $100 \%$ polyester and $100 \%$ acrylic textile materials. Therefore, our results are not in accordance with this study. 


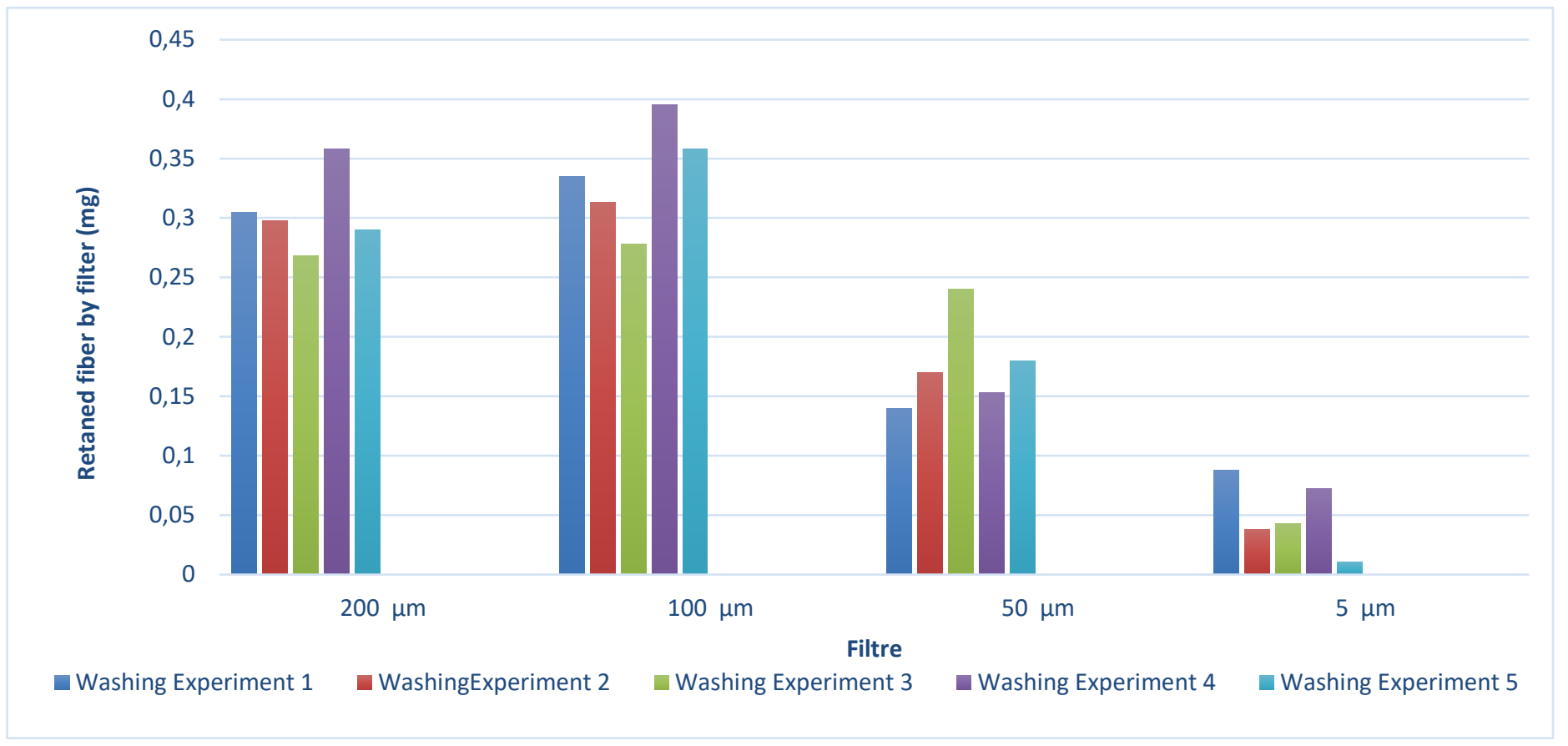

Figure 1. Retained fibres by filter in washing experiments

Table 2. Released fibre ( $\mathrm{mg} / \mathrm{l})$

\begin{tabular}{|c|c|c|c|c|c|}
\hline \multirow{2}{*}{$\begin{array}{c}\text { Washing } \\
\text { No }\end{array}$} & \multicolumn{5}{|c|}{ Filtered Microfibre (mg/l) } \\
\hline & $200 \mu \mathrm{m}$ & $100 \mu \mathrm{m}$ & $50 \mu \mathrm{m}$ & $5 \mu \mathrm{m}$ & Total (mg/l) \\
\hline 1 & $1, .22$ & 1.34 & 0.56 & 0.35 & 3.47 \\
\hline 3 & 1.07 & 1.11 & 0.96 & 0.17 & 3.31 \\
\hline 4 & $1, .43$ & 1.58 & 0.61 & 0.29 & $3, .91$ \\
\hline 5 & 1.16 & 1.43 & $0, .72$ & 0.41 & 3.72 \\
\hline
\end{tabular}

Table 3. Released fibre $(\mathrm{mg} / \mathrm{kg})$

\begin{tabular}{llllll}
\hline & \multicolumn{5}{c}{ Retained Fiber $(\mathbf{m g} / \mathbf{k g})$} \\
\hline Washing Experiment & $\mathbf{1}$ & $\mathbf{2}$ & $\mathbf{3}$ & $\mathbf{4}$ & $\mathbf{5}$ \\
\hline $200 \mu \mathrm{m}$ & 4.88 & 4.77 & 4.29 & 5.73 & 4.64 \\
$100 \mu \mathrm{m}$ & 5.36 & 5.0 & 4.45 & 6.32 & 5.73 \\
$50 \mu \mathrm{m}$ & 2.24 & 2.72 & 3.84 & 2.45 & 2.88 \\
$5 \mu \mathrm{m}$ & 1.41 & 0.61 & 0.69 & 1.16 & 0.16 \\
\hline Total & 13.89 & 13.1 & 13.27 & 15.66 & 13.41 \\
\hline
\end{tabular}




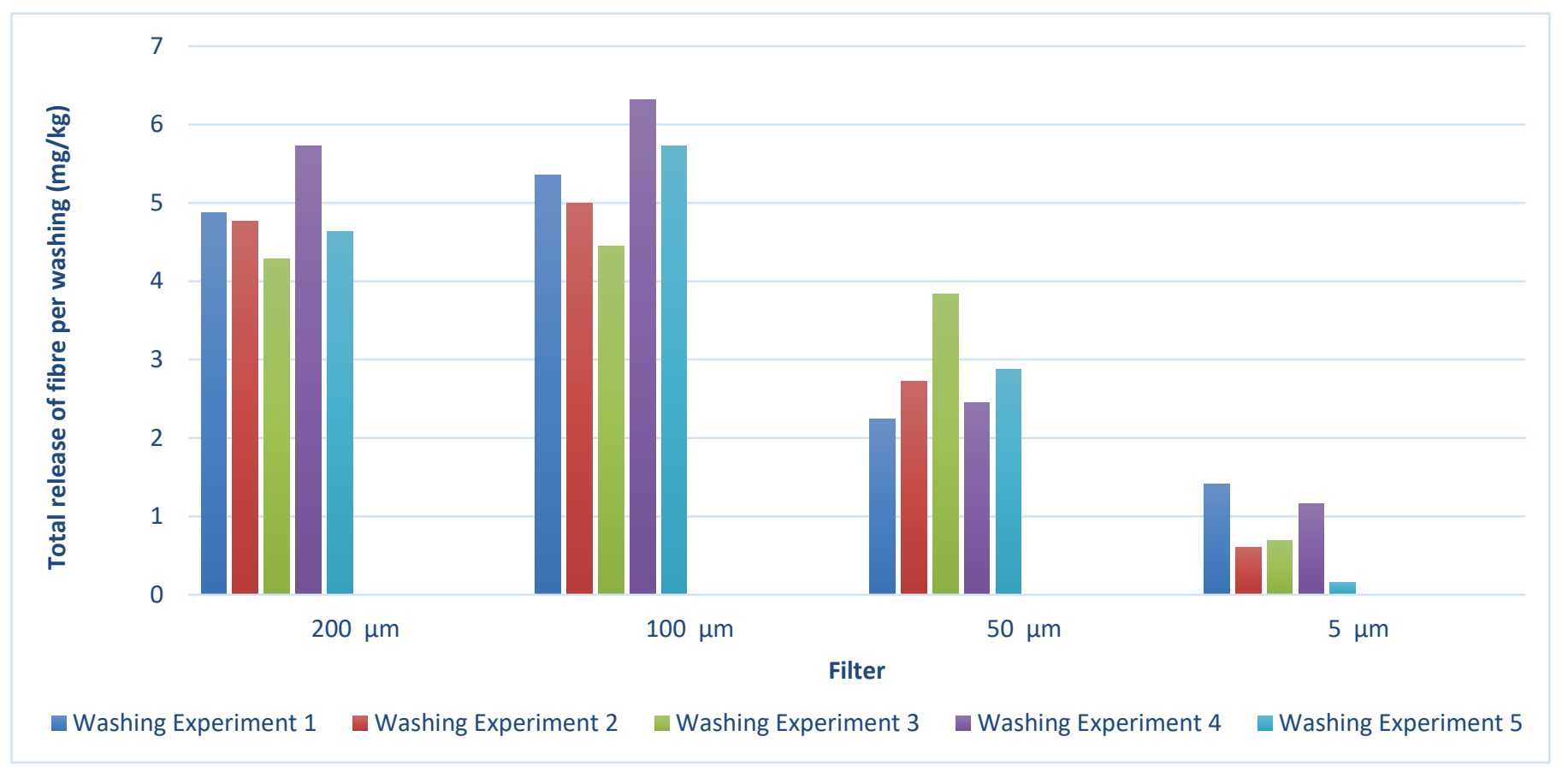

Figure 2. Total release of fibre per washing $(\mathrm{mg} / \mathrm{kg})$

\section{Conclusions and Recommendations}

Microplastics are commonly encountered in different part of the environment. This study intended to evaluate the amount of the microplastic release from domestic laundry washing. In this way, it is aimed to give an idea about the measures that can be taken by revealing the situation regarding microplastics. Folowing conclusions can be drawn as a result of the research:

$100 \mu \mathrm{m}$ filtre gave the highest fibre removal in all washing cycles. The amounts of retained microfiber through $200 \mu \mathrm{m}$ were close to amount of the retained microfiber by $100 \mu \mathrm{m}$ filter. Total removed fiber per washing varied between $3.28 \mathrm{mg} / \mathrm{l}$ and $3.91 \mathrm{mg} / 1$ for five washing cycles.

The highest amount of fibre released from 4th washing. Textile materials washed in this experiment contain $100 \%$ cotton. Washing cycle 2 , which contains $40 \%$ cotton and $60 \%$ polyeser blend, gave the lowest fibre release. Total fibre per washing was $15.66 \mathrm{mg} / \mathrm{kg}$ for Washing 4, while it was found $13.27 \mathrm{mg} / \mathrm{kg}$ for Washing 3. The higher the \% blend of cotton, resulted in higher fibre release. Although cotton is not as persistent as synthetic fibre in environment, it may contain chemical residues and plays important role in the transport of the pollutants. Further studies must be conducted to investigate the effect of washing conditions such as used detergents, softener, washing temperature, tumble rotation rate etc., in addition to textile production processes such as cutting, sewing etc. Moreover, textile manufacturers should consider these effects on microplastic release to maintain sustainable and environmentallyfriendly textile production.

\section{References}

Akçay, S., Törnük, F. \& Yetim, H. (2020). Mikroplastikler: Gidalarda bulunuşu ve sağlı üzerine etkileri. Avrupa Bilim ve Teknoloji Dergisi, (20), 530-538.

Almroth B.M.C., Åström, L., Roslund, S., Petersson, H, Johansson, M. \& Persson, N.K. (2018), Quantifying shedding of synthetic fibers from textiles; a source of microplastics released into the environment, Environmental Science and Pollution Research, 25, 1191-1199.

Baykal, P. D., Babaarslan, O. \& Erol, R. (2006). Prediction of strength and elongation properties of cotton/polyesterblended OE rotor yarns, Fibres \& Textiles in Eastern Europe, 14 (1) (55), 18-21.

Belzagui F, Crespi M, Álvarez A, Gutiérrez-Bouzán C. \& Vilaseca M (2019) Microplastics' emissions: microfibers' detachment from textile garments. Environmental Pollution 248, 1028-1035.

Boucher, J. \& Friot, D. (2017). Primary microplastics in the oceans: A Global evaluation of sources. Gland, Switzerland: IUCN. 43 pp.

Browne, M., Galloway, T. \& Thompson, R. (2007). Microplastic-an emerging contaminant of potential concern? Integrated Environmental Management and Assesment, 3, (4), 569-561.

Cai, Y., Yang, T., Mitrano, D.M., Heuberger, M., Hufenus, R. \& Nowack, B. (2020). Systematic study of microplastic release from 12 different polyester textiles during washing, Environmental Science \& Technology, 54 (8), 4847-4855.

Cesa, F.S., Turra, A., Checon, H. H, Leonardi, B. \& BaruqueRamos, J. (2020). Laundering and textile parameters influence fibers release in household washings. Environ Pollut 257:113553.

Davvergne, P. (2018). The power of environmental norms: marine plastic pollution and the polities of microbeads. Environmental Politics, 27 (4), 579-597. 
De Falco, F., Gullo, M. P., Gentile, G., Di Pace, E., Cocca, M., Gelabert, L., Brouta-Agnesa, M., Rovira, A., Escudero, R., Villalba, R., Mossotti, R., Montarsolo, A., Gavignano, S., Tonin, C. \& Avella, M. (2018). Evaluation of microplastic release caused by textile washing processes of synthetic fabrics, Environmental Pollution, 236, 916-925.

Fontana,G.D., Mossoti, R. \& Montarsolo, A. (2020). Assessment of microplastics release from polyester fabrics: The impact of different washing conditions, Enviromental Pollution, 264, 113960.

Galvao, A., Alexio, M., Pablo, H.D., Lopes, C. \& Raimundo, J. (2020). Microplastics in wastewater: microfiber emissions from common household laundry, Environmental Science and Pollution Research, 27, 26643-2649.

Jemee, A., Horvat, P., Kunej, U., Bele, M. \& Krzan, A. (2016). Uptake and effects of microplastics textile fibers on freshwater crustocceon Daphnia Magna. Environmental Pollution, 219, 201-209.

Karkkaien, N. \& Sillanpaa, M. (2021). Quantification of different microplastic fibres discharged from texiles in maschine wash and tumble drying, Environmental Sicence and Pollution Research, 2, 16253-16263.

Kelly MR, Lant NJ, Kurr M \& Burgess JG (2019) Importance of water-volume on the release of microplastic fibers from laundry. Environmental Science and Technology 53(20), 11735-11744.

Napper, I.E. \& Thompson, R.C. (2016). Release of synthetic microplastic plastic fibres from domestic washing machines: Effects of fabric type and washing conditions. Marine Pollution Bulletin, 112(1-2), 39-45. doi:10.1016/j.marpolbul.2016.09.025.

Plastics, The Facts (2020). An analysis of European plastics production, demand and waste data, Plastics Europe, Asociation of Plastics Manufacturers.

Sait, S.T.L., Sorenson, L., Kubowciz, S., Vike-Jonas, K., Gonzalez, S. V., Asimakopoulos, A. G. \& Booth, A. M. (2021). Microplastic fibres from synthetic textiles: Environmental degradation and additive chemical content, Environmental Pollution, 268 (B), 115745.

Sillanpaa, M.K. \& Sainio, P. (2017). Release of polyester and cotton fibers from textiles in machine washing, Environmental Science and Pollution Research, 24, 1931319321.

Zambrano, M. C., Pawlak, J. J., Daystar, J., Ankeny, M. \& Venditti, R. A. (2021). Impact of dyes and finishes on the aquatic biodegradability of cotton textile fibers and microfibers released on laundering clothes: Correlations between enzyme adsorption and activity and biodegradation rates, Marine Pollution Bulletin, 165, 112030. 